\title{
Pengaruh Motivasi Dan Kompensasi Terhadap Kinerja Karyawan Pada PT. Sumber Tenaga Lestari (Citylight Apartment) Tangerang Selatan
}

\author{
Gatot Kusjono $^{1}$, Putri Ratnasari ${ }^{2}$ \\ Dosen Fakultas Ekonomi Universitas Pamulang \\ Email: dosen00434@unpam.ac.id
}

\begin{abstract}
ABSTRAK
Penelitian ini bertujuan untuk mengetahui seberapa besar pengaruh motivasi dan kompensasi terhadap kinerja karyawan. Penelitian ini dilaksanakan pada PT Sumber Tenaga Lestari (Citylight Apartement) Tangerang Selatan.

Metode analisis yang digunakan adalah analisis deskriptif kuantitatif dan menggunakan metode survey terhadap 80 responden. Teknik pengumpulan data menggunakan instrumen yang berbentuk angket. Instrumen dikalibrasi dengan menggunakan validitas butir dan koefisien reliabilitas. Uji persyaratan analisis data dilakukan dengan uji normalitas, uji heteroskedastisitas, dan uji multikolnieritas. Data penelitian di analisis menggunakan analisa korelasi, determinasi dan regresi linier berganda.

Hasil penelitian diperoleh adanya pengaruh yang signifikan antara motivasi dan kompensasi dengan nilai $F_{\text {hitung }}(24,518)$ lebih beasr dari $F_{\text {tabel }}(3,11)$ dengan persamaan regresi berganda $\mathrm{Y}=18,523+0,487 \mathrm{X}_{1}+0,099 \mathrm{X}_{2}$, tingkat hubungan variabel bebas terhadap variabel terikat tergolong kuat dengan koefisien korelasi $r_{y 12}=0,624$. Sedangkan konstribusi variabel motivasi dan kompensasi terhadap kinerja karyawan ditunjukkan dengan nilai koefisien determinasi sebesar 38,9\% dan sisasnya sebesar $61,1 \%$ ditentuan variabel lain yang tidak diteliti.

variabel lain diluar penelitian ini
\end{abstract}

Kata Kunci : Motivasi, Kompensasi, dan Kinerja Karyawan. 


\section{PENDAHULUAN}

\section{A. Latar Belakang Masalah}

Dalam era globalisasi saat ini sering kali ditemukan beberapa masalah yang menyebabkan banyaknya perusahaan mengalami kegagalan, baik yang disebabkan oleh ketidakmampuan beradaptasi dengan kemajuan teknologi yang disebabkan oleh kurang baiknya hasil kerja dari sumber daya manusia yang ada pada perusahaan tersebut. Oleh karena itu, keberhasilan suatu perusahaan sangat ditentukan oleh pendayagunaan sumber daya manusia yaitu orangorang yang menyediakan tenaga, bakat kreativitas, dan semangat bagi perusahaan serta memegang peranan penting dalam fungsi peranan operasional perusahaan.

Sumber daya manusia adalah asset yang sangat penting untuk menggerakkan seluruh roda organisasi sehingga pengembangan sumber daya manusia ditempatkan pada urutan tertinggi. Untuk tercapainya tujuan suatu perusahaan maka perlu adanya pemberian motivasi dan kompensasi untuk karyawan agar mampu bekerja dengan baik. Menurut Anwar Prabu Mangkunegara (2014:61) Motivasi merupakan kondisi atau energi yang menggerakan diri karyawan yang terarah atau tertuju untuk mencapai tujuan organisasi perusahaan. Sedangkan menurut Wilson Bangun (2012:312) Motivasi berasal dari kata motif (motive) yang berarti dorongan, dengan demikian motivasi berarti suatu kondisi yang mendorong atau menjadi sebab seseorang melakukan suatu perbuatan atau kegiatan yang berlangsung secara sadar.

PT Sumber Tenaga Lestari (Citylight Apartment) merupakan perusahaan dibidang property, yakni apartment dimana karyawannya banyak memegang posisi sebagai marketing. Job desk dari seorang marketing tentu tidak bisa dikatakan mudah, karna banyak tantangan yang harus dilaksanakan. Job desk utama nya dari seorang marketing di PT Sumber Tenaga Lestari (Citylight Apartment) yakni mencari seorang calon pembeli hunian apartment dengan dana yang tinggi. Mencari seorang pembeli atau investor tentu tidak mudah, harus mempunyai skill yang tinggi agar calon investor mempercayai dana nya untuk membeli apartment tersebut. Melihat job desk yang tidak mudah, maka di perlukannya pemberian motivasi dan kompensasi.

Pemberian motivasi kepada karyawan selama ini dirasa kurang terlaksana dengan baik, yakni kurangnya sarana dan prasarana di perusahaan, lingkungan pekerjaan yang kurang menyenangkan, Masih banyak kehadiran karyawan yang prosentasenya kurang seperti: ijin, sakit, dan tidak masuk tanpa keterangan setiap bulannya.

Selain motivasi, faktor lain yang berpengaruh untuk meningkatkan kinerja karyawan adalah kompensasi. Pemberian kompensasi kepada karyawan harus mempunyai dasar yang logis dan rasional, namun demikian faktor-faktor emosional dan perikemanusiaan tidak boleh diabaikan. Menurut Siagian (2012:253) menyatakan sistem kompensasi yang baik adalah sistem yang mampu menjamin kepuasaan para anggota organisasi yang pada gilirannya memungkinkan organisasi memperoleh, memelihara dan mempekerjakan sejumlah orang yang 
memiliki sikap dan perilaku positif untuk kepentingan organisasi.

Pemberian kompensasi di PT Sumber Tenaga Lestari (Citylight Apartment) di rasa juga belum baik, dapat dilihat dari pemberian kompensasi yang diberikan belum sesuai dengan kebijakan pemerintah (belum sesuai UMR), pembayaran gaji yang tidak tepat waktu, kurangnya fasilitas mobil operasional perusahaan.

Tingkat keberhasilan suatu perusahaan dapat dilihat dari kinerja perusahaan dalam mengelola sumber daya yang dimilikinya. Perusahaan dengan kinerja yang baik, mempunyai efektifitas dalam menangani sumber daya manusianya, menentukan sasaran yang harus dicapai baik secara individu maupun organisasi. Menurut Mangkunegara (2011:67) bahwa Kinerja adalah hasil kerja secara kualitas dan kuantitas yang dicapai oleh seorang pegawai dalam melaksanakan tugasnya sesuai dengan tanggung jawab yang diberikan kepadanya.

Kinerja adalah poin yang penting dalam kemajuan perusahaan, semakin meningkatnya kinerja karyawan suatu perusahaan maka akan semakin cepat tercapainya tujuan perusahaan tersebut. Dengan meningkatnya kinerja karyawan maka perusahaan akan memperoleh keuntungan. Baik dari produktivitas karyawan maupun tercapainya tujuan perusahaan. Semakin besar kinerja karyawan maka prestasi kerja karyawan juga akan semakin cepat tercapai sehingga produktivitas dan tujuan perusahaan pun akan tercapai.

Kinerja karyawan di PT Sumber Tenaga Lestari (Citylight Apartment) dirasa kurang memuaskan untuk perusahaan, ini bisa dilihat dari hasil kerja yang tidak memberikan kepuasan kepada pihak atasan maupun bagi pihak lain, tidak terpenuhinya target yang ditetapkan perusahaan.

Berdasarkan uraian diatas, menjelaskan bahwa motivasi dan kompensasi berhubungan dengan kinerja karyawan, maka penulis tertarik untuk melakukan penelitian dengan judul : "Pengaruh Motivasi dan Kompensasi Terhadap Kinerja Karyawan pada PT Sumber Tenaga Lestari (Citylight Apartment) Tangerang Selatan".

\section{B. Batasan Masalah}

Berdasarkan identifikasi masalah diatas, maka dalam penelitian ini peneliti hanya membatasi permasalahan yaitu motivasi dan kompensasi sebagai variabel bebas (independent variable) sedangkan kinerja karyawan sebagai variabel terikat (dependent variable). Adapun lokasi penelitian dilaksanakan pada PT Sumber Tenaga Lestari (Citylight Apartment).

\section{Tujuan Penelitian}

Tujuan Penelitian adalah 1). Untuk mengetahui pengaruh motivasi terhadap kinerja karyawan di PT Sumber Tenaga Lestari (Citylight Apartment); 2) Untuk mengetahui pengaruh kompensasi terhadap kinerja karyawan di PT Sumber Tenaga Lestari (Citylight Apartment) 3). Untuk mengetahui pengaruh motivasi dan kompensasi terhadap kinerja karyawan di PT Sumber Tenaga Lestari (Citylight Apartment). 


\section{LANDASAN TEORI}

\section{A. Manajemen Sumber Daya} Manusia

Manajemen adalah alat untuk memanfaatkan sumber daya yang ada secara efektif dan efesien untuk mencapai tujuan yang telah ditetapkan. Agar tujuan yang ditetapkan tersebut dapat tercapai, maka diperlukan suatu proses manajemen terlebih dahulu. Proses manajemen terdiri dari planning (merencanakan), organizing (mengorganisasikan), actuating (mengarahkan), coordinating (mengkordinasikan), dan controlling (mengendalikan).

Manajemen berasal dari kata to manage yang berarti mengurus, mengatur, melaksanakan dan mengelola. Dalam manajemen, dibutuhkan sarana manajemen yang terdiri dari man (manusia), money (biaya), machine (mesin), materils (bahan baku), method (cara), dan market (pasar).

Dari rumusan diatas dapat menyimpulkan, manajemen secara efektif dan efesien ini dimaksud dalam melaksanakan kerja organisasi dengan menggunakan sumber daya atau organisasi harus dilakukan dengan cermat dan teliti agar tidak terjadi pemborosan.

Sumber daya manusia mempunyai potensi yang luar biasa yang menggalakan sumber daya organisasi lainnya. Perkembangan organisasi sangat bergantung pada produktivitas tenaga kerja yang ada. Oleh karna itu, tidak dapat disangkal faktor manusia merupakan modal utama yang perlu diperhatikan oleh pemimpin perusahaan. Hal ini sesuai dengan pendapat Mangkunegara (2013:2) manajemen sumber daya manusia merupakan suatu perencanaan, pengorganisasian, pengkordinasian, pelaksanaan, dan pengawasan terhadap pengadaan, pengembangan, pemberian balas jasa, pengintegrasian, pemeliharaan, dan pemisahan tenaga kerja dalam rangka mencapai tujuan organisasi.

Selain itu, menurut Yus Iswanto dan Adhie Yusuf (2011:1) manajemen sumber daya manusia disebut juga pengembangan sumber daya manusia, implementasi dan perekrutan (termasuk seleksi), pelatihan dan pengembangan karier karyawan, serta melakukan inisiatif terhadap pengembangan organisasional suatu organisasi.

\section{B. Motivasi}

Motivasi adalah suatu faktor yang mendorong seseorang untuk melakukan suatu aktivitas atau kegiatan untuk memenuhi kebutuhankebutuhan yang dinginkan.

Menurut Edi Sutrisno (2016:121) teori motivasi dikelompokkan menjadi dua aspek, yaitu teori kepuasan dan motivasi proses.

a. Teori Kepuasan,

Teori ini mendasarkan pendekatannya atas faktor-faktor kebutuhan dan kepuasan individu yang menyebabkannya bertindak dan berprilaku dengan cara tertentu. Teori ini memusatkan perhatian pada faktorfaktor dalam diri orang yang menguatkan, mengarahkan, mendukung, dan menghentikan prilakunya. Teori ini mencoba menjawab pertanyaan kebutuhan apa yang memuaskan dan mendorong semangat bekerja seseorang. Kebutuhan dan pendorong itu adalah keinginan memenuhi kepuasan material maupun non material yang diperolehnya dari hasil pekerjaannya. 


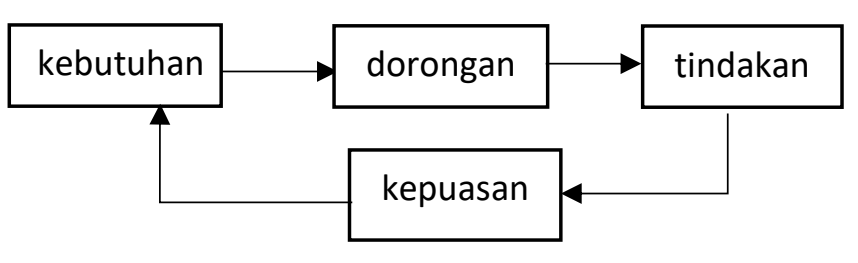

Gambar 2.1

Model Motivasi dari content theory

Jika kebutuhan dan kepuasan semakin terpenuhi, semangat bekerjanya pun akan semakin baik pula. Jadi pada dasarnya teori ini mengemukakan bahwa seseorang akan bertindak untuk dapat memenuhi kebutuhan dan kepuasannya. Semakin tinggi standar kebutuhan kebutuhan dan kepuasan yang diinginkan, semakin giat orang itu bekerja. Tinggi atau rendahnya tingkat kebutuhan dan kepuasan yang ingin dicapai seseorang mencerminkan semangat bekerja orang tersebut.

Penganut content theory ini cukup banyak, yang satu sama lain sebenarnya tidak mempunyai kaitan. Akan tetapi, berdasarkan penelitian yang dilakukan mereka, ternyata hasil penemuannya dapat dimasukkan dalam teori kebutuhan. Teori kepuasan tersebut di pelopori oleh F. W. Taylor, Abraham H. Maslow, David McClelland, Frederick Hezberg, Clayton P. Alder, Douglas Mc Gregor.

b. Teori Motivasi Proses,

Ada tiga teori motivasi proses yang lazim dikenal, yaitu :

1) Teori harapan (Expectacy Theory)

Teori harapan menyatakan bahwa kekuatan yang memotivasi seseorang bekerja giat dalam melaksanakan pekerjaannya bergantung pada hubgungan timbal balik antara apa yang ia inginkan dengan kebutuhan dari hasil pekerjaan itu. Berapa besar ia yakin perusahaan akan memberikan pemuasan bagi keinginan sebagai imbalan atas usaha yang dilakukannya itu. Bila keyakinan yang diharapkan cukup besar untuk memperoleh kepuasannya, ia akan bekerja keras pula, dan sebaliknya. Teori harapan didasarkan atas harapan, nilai, dan pertautan.

Kalau dicermati, teori ini mengandung tiga variabel, yaitu daya tarik, hubungan antara prestasi kerja dengan imbalan, serta hubungan antara usaha dengan prestasi kerja. Yang dimaksud dengan daya tarik ialah sampai sejauh mana seseorang merasa pentingnya hasil yang diperoleh dalam menyelesaikan tugasnya. Yang dimaksud dengan kaitan antara prestasi dengan imbalan ialah tingkat keyakinan seseorang tentang hubungan antra tingkat prestasi kerja dengan pencapaian hasil tertentu. Adapun kaitan antara usaha dengan prestasi ialah persepsi seseorang tentang kemungkinan bahwa usaha tertentu akan menjurus kepada prestasi.

2) Teori Keadilan (Equity Theory)

Teori ini menekankan bahwa ego manusia selalu mendambakan keadilan dalam pemberian hadiah maupun hukuman terhadap setiap perilaku yang relative sama. Bagaimana perilaku bawahan dinilai oleh atasan akan mempengaruhi semangat kerja mereka. Keadilan merupakan daya penggerak yang memotivasi semangat kerja seseorang. Jadi, atasan harus bertindak adil terhadap semua bawahannya. Penilaian dan pengakuan 
mengenai perilaku bawahan harus dilakukan secara objektif, bukan atas dasar suka atau tidak suka. Pemberian kompensasi atau hukuman harus berdasarkan penilaian objektif dan adil. Jika prinsip ini diterapkan dengan baik oleh pimpinan semangat kerja bawahan cenderung akan meningkat.

3) Teori Pengukuhan

Teori pengukuhan didasarkan atas hubungan sebab dan akibat perilaku dengan pemberian kompensasi. Misalnya, promosi bergantung pada prestasi yang selalu dapat dipertahankan. Bonus kelompok bergantung pada tingkat produksi kelompok itu. Sifat ketergantungan terseut bertautan dengan hubungan dengan perilaku dan kejadian yang mengikuti perilaku itu. Jadi prinsipnya pengukuhan selalu berhubungan dengan bertambahnya frekuensi dan tanggapan, apabila diikuti oleh stimulus yang bersyarat. Demikian juga prinsip hukuman selalu berhubungan dengan berkurangnya frekuensi respons. Dan teori proses ini bermanfaat apabila manajer telah betul-betul mengenal bawahan dan kepribadian individual mereka, dan ini kadang-kadang tidak mudah. Terlebih lagi karyawan yang mengalami ketidakadilan dimasa lalu atau kebutuhan keamanannya tidak terpenuhi lambat mempercayai manajer dan mengungkapkan imbalan apa yang paling bervalensi bagi mereka. akan tetapi, kelemahan ini dapat diatasi jika para manajer secara cermat menetapkan standar yang jelas atas kinerja yang dapat diterima dan sistem imbalan ekstrinsik yang pantas. Mereka juga sebaiknya ingat walaupun valensi dari imbalan tertentu akan bervariasi setiap pribadi, kepuasan untuk melakukan pekerjaan yang baik secara intrinsik dialami hampir setiap orang. Maka, tugas manajer adalah menjadi yakin bahwa para karyawan memiliki sumbernya yang mereka butuhkan untuk bekerja sebaik mungkin.

\section{Kompensasi}

Kompensasi adalah semua jenis penghargaan yang berupa uang atau bukan yang diberikan kepada karyawan secara layak dan adil atas jasa mereka dalam mencapai tujuan perusahaan (Edy Sutrisno:2016,187). Seperti yang dinyatakan Trinton (2010:124) kompensasi adalah semua balas jasa baik berbentuk uang, barang langsung atau tidak langsung yang diberikan kepada karyawan atas kontribusi karyawan dalam mencapai tujuan atau sasaran.

Menurut M. Kadarisman (2012:1) kompensasi adalah apa yang seorang karyawan/pegawai/pekerja terima sebagai balasan dari pekerjaan yang diberikannya. Selain itu, Sarinah Sihombing (2013:101) menyatakan kompensasi adalah semua pendapatan yang berbentuk uang atau barang atau tidak langsung yang diterima karyawan sebagai imbalan balas jasa yang diberikan kepada perusahaan.

Berdasarkan dari beberapa pendapat ahli diatas, maka penulis dapat menyimpulkan bahwa kompensasi merupakan segala sesuatu yang diterima oleh karyawan sebagai balas jasa untuk kerja mereka. 


\section{Jenis-Jenis Kompensasi}

Menurut Sarinah Sihombing (2013:104) jenis-jenis Kompensasi dapat dibedakan menjadi dua bentuk, yaitu :

a. Kompensasi dalam bentuk financial

Kompensasi financial dibagi menjadi dua bagian, yaitu kompensasi financial yang dibayarkan secara langsung seperti gaji, upah, komisi, dan bonus. Kompensasi financial yang diberikan secara tidak langsung, seperti tunjangan kesehatan, tunjangan pensiun, tunjangan hari raya, tunjangan perumahan, tunjangan pendidikan dan lain sebagainya.

b. Kompensasi dalam bentuk non financial

Kompensasi non financial dibagi menjadi dua macam, yaitu yang berhubungan dengan pekerjaan dan lingkungan kerja. Yang berhubungan dengan pekerjaan, misalnya kebijakan perusahaan yang sehat, pekerjaan yang sesuai, peluang untuk dipromosikan, mendapat jabatan sebagai simbol status. Sedangkan kompensasi non financial yang berhubungan dengan lingkungan kerja, seperti ditempatkan dilingkungan kerja yang kondusif, fasilitas kerja yang baik dan lain sebagainya.

\section{Kinerja Karyawan}

Kinerja karyawan adalah terjemahan dari performance yang berarti hasil kerja atau prestasi kerja. Dan dalam pengertian yang simpel kinerja karyawan adalah hasil dari pekerjaan organisasi yang dikerjakan oleh karyawan dengan sebaik-baiknya sesuai dengan petunjuk (manual), arahan yang diberikan oleh pimpinan (manajer), kompetensi dan kemampuan karyawan mengembangkan nalarnya dalam bekerja (Abdullah: 2013, 331).

Menurut Mangkunegara
(2011:67) kinerja karyawan adalah hasil kerja secara kualitas dan kuantitas yang dicapai oleh seorang pegawai dalam melaksanakan tugasnya sesuai dengan tanggung jawab yang diberikan kepadanya.

Menurut Irham Fahmi (2013:127) kinerja adalah hasil yang diperoleh oleh suatu organisasi baik organisasi tersebut bersifat profit oriented dan non profit yang dihasilkan selama satu periode waktu.

\section{Tujuan Penilaian Kinerja \\ Karyawan}

Tujuan dari penilaian kinerja menurut Sedarmayanti (2010:264) antara lain:

a. Membantu meningkatkan kinerja

b. Menetapkan sasaran bagi kinerja perorangan

c. Menilai kebutuhan pelatihan dan pengembangan

d. Menyepakati rencana untuk pengembangan karyawan dimasa depan

e. Menilai potensi dimasa depan untuk kenaikan pangkat

f. Memberi umpan balik kepada karyawan mengenai kinerja mereka

g. Memberi konsultasi kepada karyawan mengenai peluang karir

h. Menentukan taraf kinerja karyawan untuk maksud peninjau gaji

i. Mendorong pemimpin untuk berfikir cermat mengenai kinerja staf pada umumnya dan factor yang mempengaruhi termasuk 
gaya kepemimpinan dan perilaku mereka sendiri.

\section{Manfaat penilaian Kinerja Karyawan}

Menurut Irham Fahmi (2013:137) penilaian kinerja karyawan dimanfaatkan oleh manajemen untuk :

a. Mengelola operasi organisasi secara efektif dan efesien melalui pemotivasian karyawan secara maksimum

b. Membantu pengambilan keputusan yang bersangkutan dengan karyawan, seperti : promosi, transfer, dan pemberhentian c. Mengidentifikasi kebutuhan pelatihan dan pengembangan karyawan dan untuk menyediakan kriteria seleksi dan evaluasi program pelatihan karyawan

d. Menyediakan umpan balik bagi kinerja mengenai bagaimana atasan mereka menilai kinerja mereka

e. Menyediakan suatu dasar bagi distribusi penghargaan.

\section{E. Kerangka Berfikir Penelitian}

Berdasarkan asumsi uraian di atas dapat disimpulkan kerangka berpikir yang tergambar dibawah ini dengan indikator-indikator sebagai berikut:

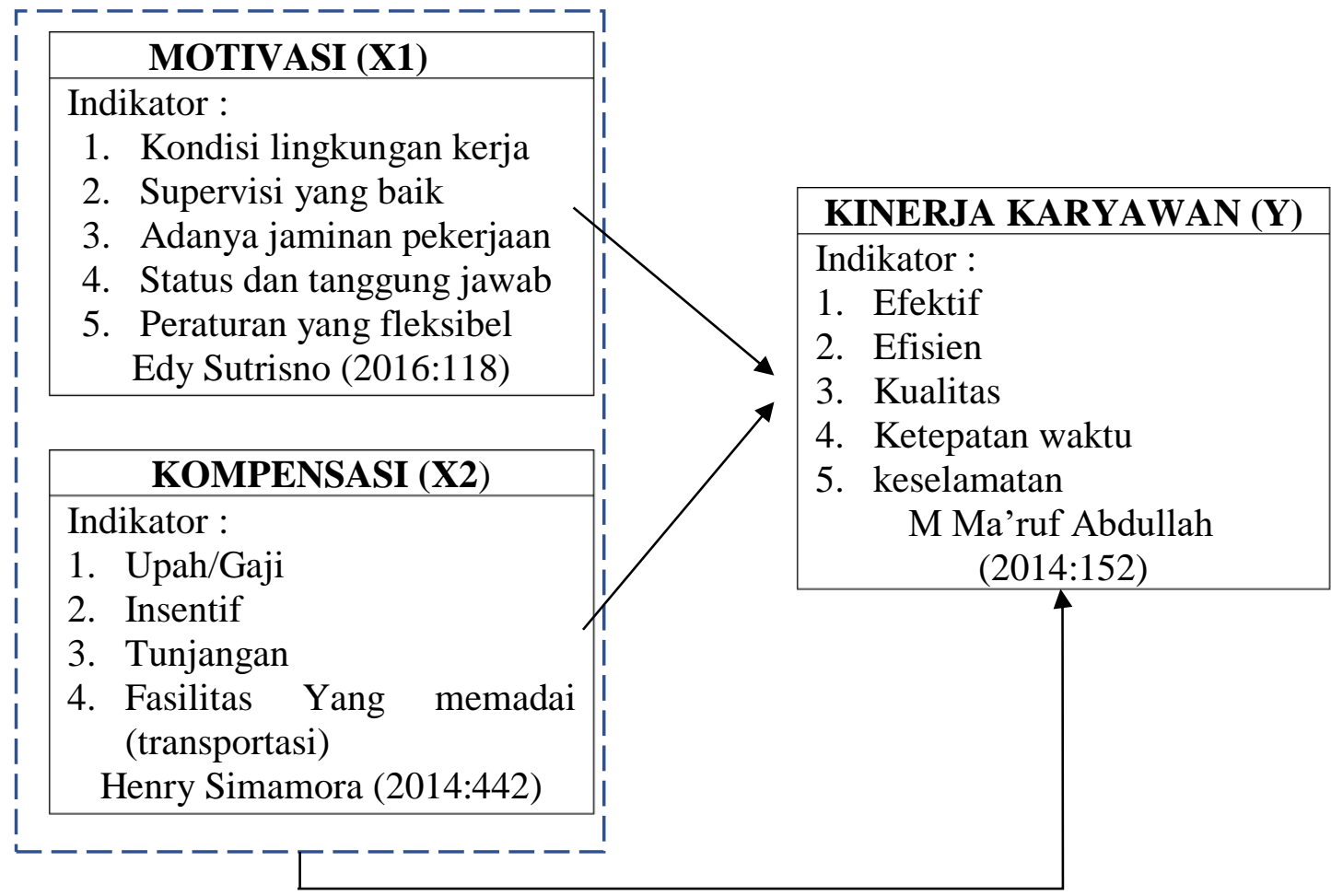

Gambar 2.2 Kerangka Berfikir Penelitian

\section{F. Hipotesis}

Menurut Sugiyono (2011:64) Hipotesis adalah dugaan yang menjelaskan suatu fenomena yang belum terbukti kebenarannya sehingga perlu diuji secara empiris untuk membuktikan kebenarannya. Dengan hipotesis ini diduga ada pengaruh antara motivasi dan kompensasi terhadap kinerja karyawan pada PT 
Sumber Tenaga Lestari (Citylight Apartment). Adapun hipotesis dalam penelitian ini adalah sebagai berikut :

1. $\mathrm{HO}_{1}: \beta=0$, diduga tidak terdapat pengaruh yang signifikan variabel motivasi terhadap variabel kinerja karyawan.

$\mathrm{Ha}_{1}: \beta \neq 0$, diduga terdapat pengaruh variabel motivasi terhadap variabel Kinerja karyawan.

2. $\mathrm{HO}_{2}: \beta=0$, diduga tidak terdapat pengaruh yang signifikan variabel kompensasi terhadap variabel kinerja karyawan.

$\mathrm{Ha}_{2}: \beta \neq 0$, diduga terdapat pengaruh variabel kompensasi terhadap variabel Kinerja karyawan.

3. $\mathrm{HO}_{3}: \beta=0$, diduga tidak terdapat pengaruh yang signifikan variabel motivasi dan variabel kompensasi terhadap variabel kinerja karyawan.

$\mathrm{Ha}_{3}: \beta \neq 0$, diduga terdapat pengaruh variabel motivasi dan variabel kompensasi terhadap variabel Kinerja karyawan.

\section{METODELOGI PENELITIAN}

\section{A. Populasi dan Sampel}

Populasi merupakan objek atau subjek yang berada pada suatu wilayah dan memenuhi syaratsyarat tertentu berkaitan dengan masalah penelitian. Populasi yang dimaksud disini adalah karyawan PT Sumber Tenaga Lestari (Citylight Apartment) yang berjumlah 80 orang. Sedangkan sampel yang digunakan adalah sampling jenuh, yakni keseluruhan populasi digunakan sebagai sampel dalam penelitian,.

\section{B. Metode Pengumpulan Data}

Menurut sumber datanya, pengumpulan data dibagi menjadi sumber primer dan sumber sekunder. Sumber primer adalah sumber data yang langsung memberikan data kepada pengumpulan data, dan sumber sekunder merupakan sumber yang tidak langsung memberikan data kepada pengumpulan data (Sugiyono 2010:193).

1. Data Primer

Data primer adalah data yang diperoleh langsung dari sumbernya yang diamati langsung untuk pertama kalinya oleh peneliti (tidak melalui perantara). Data primer diperoleh oleh peneliti untuk menjawab pertanyaan penelitian. Ada dua metode yang dapat dilakukan dalam pengumpulan data primer, yaitu metode survei dan metode observasi.

2. Data Sekunder

Data sekunder merupakan data yang bukan diusahakan oleh peneliti sendiri melainkan sudah dikumpulkan oleh orang lain. Tipe-tipe data sekunder, yaitu :

\section{Metode Analisis Data}

1. Analisis deskriptif

Metode analisis yang digunakan dalam penelitian ini adalah analisis deskritif kuantitatif. Metode ini bertujuan untuk menggambarkan sifat sesuatu yang tengah berlangsung pada saat riset dilakukan dan memeriksa sebab-sebab dari suatu gejala tertentu Sugiyono (2011:147).

Tahapan-tahapan yang dilakukan dalam analisa diskriptif: 
a. Peneliti melakukan pengumpul-an data, kemudian ditentukan alat untuk memperoleh data dari elemenelemen yang akan diselidiki menggunakan kue-sioner. Adapun alternatif jawaban diukur dengan meng-gunakan skala likert.

Tabel 1.1

Alternatif jawaban Responden

\begin{tabular}{|c|l|c|}
\hline No & \multicolumn{1}{|c|}{$\begin{array}{c}\text { Alternatif } \\
\text { Jawaban }\end{array}$} & $\begin{array}{c}\text { Bobot } \\
\text { Nilai }\end{array}$ \\
\hline 1 & $\begin{array}{l}\text { SS (Sangat } \\
\text { Setuju) }\end{array}$ & 5 \\
\hline 2 & S (Setuju) & 4 \\
\hline 3 & C (Cukup) & 3 \\
\hline 4 & $\begin{array}{l}\text { TS (Tidak } \\
\text { Setuju) }\end{array}$ & 2 \\
\hline 5 & $\begin{array}{l}\text { STS (Sangat } \\
\text { Tidak Setuju) }\end{array}$ & 1 \\
\hline
\end{tabular}

Sumber :Sugiyono (2012:93)

b. Ketika data tersebut terkumpul, kemudian dilakukan pengolahan data dan disajikan dalam bentuk tabel dianalisis. Dalam pe-nelitian peneliti mengguna-kan analisis deskriptif atas varibel independen dan dependennya yang selanjutnya dilakukan pengklasifikasian terhadap jumlah total skor responden. Kemudian untuk menentukan kategori jawaban responden masing-masing variabel, apakah tergolong tinggi, rendah atau sedang, terlebih dahulu ditetap-kan kelas intervalnya berdasar-kan alternatif jawaban dari masingmasing responden, ditentukan kelas intervalnya dengan perhitungan:
(Skor teringgi- Skor Terendah) dibagi banyaknya bilangan

Maka diperoleh (5-1): $5=0,80$ Dengan demikian kategori skala rata-rata jawaban dapat ditentu-kan sebagai berikut :

Tabel 1.2

Kategori Skala Jawaban

\begin{tabular}{|l|l|}
\hline Skala & Kategori \\
\hline $1,00-1,80$ & Sangat Rendah \\
\hline $1,81-2,60$ & Rendah \\
\hline $2,61-3,40$ & Sedang \\
\hline $3,41-4,20$ & Tinggi \\
\hline $4,21-5,00$ & Sangat Tinggi \\
\hline
\end{tabular}
(2012:102)

2. Uji Kualitas Data

Uji kualitas data digunakan untuk melihat apakah data layak untuk diuji dalam penelitian. Dalam penelitian ini terdapat dua pengujian data, (a) uji validitas, (b) uji reliabilitas menggunakan software SPSS 22.

3. Uji Asumsi Klasik

Pengujian asumsi klasik yang digunakan meliputi uji normalitas, uji heteroskedastisitas, dan uji multikolinieritas, adapun alat stasitik yang digunakan untuk mengolah data yaitu menggunakan software SPSS 22.

4. Koefesien Determinasi

Koefesien determinasi $\left(\mathrm{R}^{2}\right)$ pada intinya bertujuan untuk mengukur seberapa jauh kemampuan model dalam menerangkan variasi variabel dependen. Kriteria untuk menganalisis koefesien determinasi adalah :

a. Jika KD mendekati nilai 0 , berarti pengaruh independent atau variabel motivasi $\left(\mathrm{X}_{1}\right)$ dan 
kompensasi $\left(\mathrm{X}_{2}\right)$ terhadap dependent atau variabel kinerja karyawan (Y) adalah lemah.

b. Jika KD mendekati nilai 1 , berarti pengaruh independent atau variabel motivasi $\left(\mathrm{X}_{1}\right)$ dan kompensasi $\left(\mathrm{X}_{2}\right)$, terhadap dependent atau variabel kinerja karyawan (Y)

5. Uji Hipotesis

Untuk memperkuat hasil perhitungan yang diperoleh dan untuk mengetahui tingkat signifikasi pengaruh variabel bebas $(\mathrm{X})$ terhadap variabel terikat (Y) maka dilakukan uji hipotesis dengan langkah-langkah sebagai berikut :

a. Uji Parsial (Uji t)

Menurut Sugiyono (2012:99) uji parsial (uji t) digunakan untuk menguji hipotesis secara parsial guna menunjukan pengaruh tiap variabel independen secara sendiri terhadap variabel dependen. Hasil uji $t$ ini pada output SPSS dapat dilihat pada tabel Coefficients.

Kriteria pengambilan keputusan :

1) H0 ditolak jika t statistik < 0,005 atau thitung $>$ ttabel.

2) HO diterima jika t statistik > 0,005 atau thitung $<$ ttabel.

\section{b. Uji Simultan (Uji F)}

Menurut Sugiyono (2012:112), uji simultan (uji F) adalah uji bersama-sama seluruh variabel independen terhadap variabel dependen. Perhitungan statistik uji F dari ANOVA dilakukan dengan membandingkan nilai kritis yang diperoleh dari tabel distribusi uji $\mathrm{F}$ pada tingkat signifikansi tertentu. Hipotesis yang digunakan yaitu :

$\mathrm{HO}_{3}: \beta=0$, berarti variabel independen keseluruhan

tidak

berpengaruh terhadap variabel dependen. Jika Fhitung < Ftabel berarti Ho diterima atau variabel independen secara bersamsama tidak berpengaruh terhadap variabel dependen.

$\mathrm{Ha}_{3}: \quad \beta \neq 0$, berarti variabel independen secara keseluruhan berpengaruh terhadap variabel dependen. Jika Fhitung > Ftabel berarti Ho ditolak atau variabel independen secara bersamsama berpengaruh terhadap variabel dependen.

6. Analisis Regresi Linear Berganda

Untuk mencapai tujuan penelitian, maka data yang telah yang telah diperoleh perlu dianalisis. Dalam penelitian ini digunakan model analisis regresi berganda (multiple regression analysis). Model ini digunakan karena penulis ingin mengetahui pengaruh variabel motivasi $\left(\mathrm{X}_{1}\right)$, kompensasi $\left(\mathrm{X}_{2}\right)$ terhadap kinerja karyawan (Y).

Persamaan regresinya adalah sebagai berikut :

$$
Y=\alpha+\beta_{1} X_{1}+\beta_{2} X_{2}+e
$$

Dimana:

$\alpha=$ nilai intersep (konstan)

$\beta=$ Koefesien arah regresi

$\mathrm{X}_{1}=$ Motivasi

$\mathrm{X}_{2}=$ Kompensasi

$\mathrm{e}=$ Error term

$\mathrm{Y}=$ Kinerja Karyawan 


\section{HASIL PENELITIAN DAN}

PEMBAHASAN

\section{A. Hasil Penelitian}

\section{Analisis Jawaban kuesioner}

Analisa deskriptif adalah bagian dari statistik yang digunakan untuk menggambarkan atau mendeskripsikan data tanpa bermaksud menggeneralisir atau membuat kesimpulan tapi hanya menjelaskan kelompok data itu saja. Analisa deskriptif dapat meliputi beberapa hal diantaranya distribusi frekuensi jawaban. a. Instrument Variabel Motivasi

Penilaian karyawan terhadap Motivasi merupakan salah satu indikator mengenai Motivasi yang diterapkan oleh perusahaan dan data penilaian ini diperoleh berdasarkan hasil kuesioner yang disebarkan kepada karyawan sebanyak 80 orang diperoleh jumlah total skor-jawaban responden sebagai berikut :

Table 1.3

Rata-Rata Penilaian Karyawan Terhadap Variabel Motivasi

\begin{tabular}{|c|c|c|c|c|c|c|c|c|c|}
\hline \multirow{2}{*}{$\begin{array}{l}\text { Indi } \\
\text { kator }\end{array}$} & \multicolumn{5}{|c|}{ Frekuensi Jawaban } & \multirow{2}{*}{$\mathrm{N}$} & \multirow{2}{*}{$\begin{array}{c}\text { Jumlah } \\
\text { Skor }\end{array}$} & \multirow{2}{*}{ Mean } & \multirow{2}{*}{ Penilaian } \\
\hline & SS & $S$ & $\mathrm{C}$ & $\mathrm{TS}$ & STS & & & & \\
\hline 1 & 40 & 54 & 66 & 67 & 13 & 240 & 761 & 3,17 & Sedang \\
\hline 2 & 44 & 87 & 78 & 28 & 3 & 240 & 861 & 3,58 & Tinggi \\
\hline 3 & 32 & 91 & 82 & 33 & 2 & 240 & 838 & 3,49 & tinggi \\
\hline 4 & 68 & 81 & 67 & 24 & 0 & 240 & 913 & 3,80 & tinggi \\
\hline 5 & 14 & 33 & 25 & 5 & 3 & 80 & 290 & 3,62 & tinggi \\
\hline & & & $a-n$ & & vas & & & 3,53 & Tinggi \\
\hline
\end{tabular}

Sumber : Hasil pengolahan Data 2017

Hasil perhitungan diatas menunjukan bahwa motivasi masuk kedalam kriteria tinggi, hal ini dapat dilihat dari skor rata-rata yang dihasilkan sebesar 3,53 dan berdasarkan rentang skor rata-rata berada pada interval 3,41 - 4,20 yang berarti masuk dalam klasifikasi penilaian tinggi. Akan tetapi masih beberapa aspek yang masih belum optimal yaitu kondisi lingkungan pekerjaan kurang menyenangkan dan kurang sarana dan prasarana diperusahaan. Untuk lebih meningkatkan motivasi maka perusahaan perlu memperhatikan semua indikator yang ada dalam penelitian ini terutama indikator pertama yaitu kondisi lingkungan kerja.

b. Instrumen Variabel Kompensasi Penilaian karyawan terhadap Kompensasi merupakan salah satu indikator mengenai Kompensasi yang diterapkan oleh perusahaan dan data penilaian ini diperoleh berdasarkan hasil kuesioner yang disebarkan kepada karyawan sebanyak 80 orang diperoleh jumlah total skorjawaban responden sebagai berikut : 
Table 1.4

Rata-Rata Penilaian Karyawan Terhadap Variabel kompensasi

\begin{tabular}{|c|c|c|c|c|c|c|c|c|c|}
\hline \multirow{2}{*}{$\begin{array}{l}\text { Indi } \\
\text { kator }\end{array}$} & \multicolumn{5}{|c|}{ Frekuensi Jawaban } & \multirow[b]{2}{*}{$\mathrm{N}$} & \multirow{2}{*}{$\begin{array}{c}\text { Jumlah } \\
\text { Skor }\end{array}$} & \multirow{2}{*}{ Mean } & \multirow{2}{*}{ Penilaian } \\
\hline & SS & $\mathrm{S}$ & $\mathrm{C}$ & TS & STS & & & & \\
\hline 1 & 15 & 200 & 104 & 79 & 2 & 400 & 1.347 & 3,36 & Sedang \\
\hline 2 & 5 & 93 & 70 & 69 & 3 & 240 & 748 & 3,11 & Sedang \\
\hline 3 & 49 & 136 & 14 & 31 & 10 & 240 & 903 & 3,76 & Tinggi \\
\hline 4 & 8 & 35 & 11 & 3 & 23 & 80 & 242 & 3,02 & Sedang \\
\hline \multicolumn{8}{|c|}{ Rata-rata Kompensasi } & 3,31 & Sedang \\
\hline
\end{tabular}

Sumber : Hasil pengolahan Data 2017

Hasil perhitungan diatas menunjukan bahwa kompensasi masuk kedalam kriteria sedang, hal ini dapat dilihat dari skor rata-rata yang dihasilkan sebesar 3,31 dan berdasarkan rentang skor rata-rata berada pada interval 2,61 - 3,40 yang berarti masuk dalam klasifikasi penilaian sedang.. Untuk meningkatkan kompensasi perusahaan perlu memberikan tunjangan dan gaji yang sesuai bagi karyawan. c. Instrument Variabel Kinerja Karyawan

Penilaian karyawan terhadap kinerja merupakan salah satu indikator mengenai kinerja yang diterapkan oleh perusahaan dan data penilaian ini diperoleh berdasarkan hasil kuesioner yang disebarkan kepada karyawan sebanyak 80 orang diperoleh jumlah total skor-jawaban responden sebagai berikut :

Tabel 1.5

Rata-Rata Penilaian Karyawan Terhadap Variabel kinerja Karyawan

\begin{tabular}{|c|c|c|c|c|c|c|c|c|c|}
\hline \multirow{2}{*}{$\begin{array}{l}\text { Indi } \\
\text { kator }\end{array}$} & \multicolumn{5}{|c|}{ Frekuensi Jawaban } & \multirow{2}{*}{$\mathrm{N}$} & \multirow{2}{*}{$\begin{array}{c}\text { Jumlah } \\
\text { Skor }\end{array}$} & \multirow{2}{*}{ Mean } & \multirow{2}{*}{ Penilaian } \\
\hline & $\mathrm{SS}$ & $\mathrm{S}$ & $\mathrm{C}$ & TS & STS & & & & \\
\hline 1 & 26 & 82 & 77 & 52 & 3 & 240 & 796 & 3,46 & Tinggi \\
\hline 2 & 41 & 60 & 45 & 14 & 0 & 160 & 608 & 3,80 & Tinggi \\
\hline 3 & 17 & 56 & 62 & 25 & 0 & 160 & 545 & 3,40 & Sedang \\
\hline 4 & 24 & 90 & 103 & 23 & 0 & 240 & 835 & 3,47 & Tinggi \\
\hline 5 & 24 & 91 & 70 & 54 & 1 & 240 & 803 & 3,34 & Sedang \\
\hline & & Rata & ta & erj & Kar & van & & 3,49 & Tinggi \\
\hline
\end{tabular}

Sumber : Hasil pengolahan Data 2017

Hasil perhitungan diatas menunjukan bahwa kinerja Karyawan masuk kedalam kriteria tinggi, hal ini dapat dilihat dari skor rata-rata yang dihasilkan sebesar
3,45 dan berdasarkan rentang skor rata-rata berada pada interval $3,41-$ 4,20 yang berarti masuk dalam klasifikasi penilaian tinggi. Namun masih ada beberapa indikator 
masuk kedalam kriteria sedang yaitu indicktor efektif, kualitas, dan keselamatan. Untuk lebih meningkatkan kinerja karyawan perusahaan perlu memperhatikan peralatan keselamatan kerja di setiap unit, pekerjaan dengan tepat waktu, pekerjaan karyawan bisa menekan anggaran perusahaan seminim mungkin, Karyawan smelakukan pekerjaan dengan prosedur yang benar dan perusahaan menyediakan fasilitas yang lengkap untuk menunjang keefektivan kerja

\section{Analisis Regresi Linear berganda} Untuk mengetahui prediksi perubahan nilai variable dependen (Y) yang diakibatkan pengaruh beberapa variable independen $\left(\mathrm{X}_{1}\right.$ dan $\mathrm{X}_{2}$ ) digunakan analisis regresi linear berganda. Hasil pengolahan menggunakan program SPSS versi 22, diperoleh nilai konstanta, koefisien, dan $t_{\text {hitung, }}$ seperti ditunjukkan dalam tabel berikut:

Tabel 1.6

Hasil Uji Analisa Regresi Linear Berganda

\begin{tabular}{|l|l|l|l|l|l|}
\hline \multicolumn{7}{|c|}{ Coefficients $^{\mathbf{a}}$} \\
\hline \multirow{2}{*}{ Model } & $\begin{array}{l}\text { Unstandardized } \\
\text { Coefficients }\end{array}$ & $\begin{array}{l}\text { Standardized } \\
\text { Coefficients }\end{array}$ & & \\
\cline { 2 - 7 } & $\mathrm{B}$ & $\begin{array}{l}\text { Std. } \\
\text { Error }\end{array}$ & Beta & $\mathrm{t}$ & Sig. \\
\hline 1 (Constant) & 18.523 & 3.976 & & 4.659 & .000 \\
\hline Motivasi & .487 & .124 & .548 & 3.915 & .000 \\
\hline Kompensasi & .099 & .147 & .095 & .676 & .501 \\
\hline
\end{tabular}

a. Dependent Variable: Kinerja Karyawan

Sumber : Output SPSS 22

Dari perhitungan regresi yang telah diolah, diperoleh nilai a sebesar 18,523 nilai $b_{1}$ sebesar 0,487 dan nilai $b_{2}$ sebesar 0,099 , sehingga bentuk persamaan regresinya adalah sebagai berikut .

$$
Y=18,523+0,487 X_{1}+0,099 X_{2}
$$

Persamaan regresi diatas mempunyai arti :

1) Nilai kostanta (a) sebesar 18,523 meskipun tanpa adanya pengaruh variabel Motivasi $\left(\mathrm{X}_{1}\right)$ dan Kompensasi $\left(\mathrm{X}_{2}\right)$, maka karyawan tetap memiliki kinerja sebesar 18,523.

2) $\mathrm{b}_{1}=0,487$, merupakan koefisien arah regresi linear yang positif, artinya bahwa setiap kenaikan motivasi $\left(\mathrm{X}_{1}\right)$ sebesar satu satuan, maka kinerja (Y) akan meningkat sebesar 0,487 dengan asumsi kompensasi $\left(\mathrm{X}_{2}\right)$ dianggap konstan.

3) b2 = 0,099 merupakan koefisien arah regresi linear yang positif, artinya bahwa setiap kenaikan kompensasi $\left(\mathrm{X}_{2}\right)$ sebesar satu satuan, maka kinerja (Y) akan meningkat sebesar 0,099 dengan asumsi motivasi $\left(\mathrm{X}_{1}\right)$ dianggap konstan.

Berdasarkan nilai taraf signifikan pada $\alpha=5 \%$ pada 
tabel 1.6, maka kedua variabel independen (motivasi dan kompensasi), maka dapat disimpulkan bahwa variabel Kinerja dipengaruhi oleh variabel motivasis secara signifikan dengan $\alpha<5 \%$ dan sedangkan kompensasi pengaruhnya tidak signifikan karena nilai $\alpha>5 \%$.
3. Koefisien Korelasi Ganda (R) Untuk mengetahui seberapa kuat tingkat hubungan variabel independen terhadap variabel dependen dan arah korelasi yang terjadi maka dilakukan analisis korelasi.. Dari hasil perhitungan SPSS versi 22 diperoleh nilai koefisien korelasi (R) seperti ditunjukkan pada Tabel 1.7.

Tabel 1.7

Korelasi Nilai R dan R Square variabel $X_{1}$ dan $X_{2}$ terhadap variabel $Y$

\begin{tabular}{|l|r|r|r|r|}
\hline \multicolumn{5}{|c|}{ Model Summary } \\
\hline Model & R & R Square & $\begin{array}{l}\text { Adjusted } \\
\text { R Square }\end{array}$ & $\begin{array}{c}\text { Std. Error } \\
\text { of the Estimate }\end{array}$ \\
\hline 1 & & & & \\
\hline
\end{tabular}

a. Predictors: (Constant), Motivasi, Kompensasi

b. Dependent Variable: Kinerja

Sumber: Data diolah, 2017

Berdasarkan data di atas diperoleh nilai $\mathrm{R}$ sebesar 0,624 karena terletak pada kisaran $0,60-$ 0,79 sehingga korelasinya adalah korelasi kuat yang artinya korelasi antara motivasi dan kompensasi terhadap kinerja karyawan adalah sangat lemah.

\section{Koefisien Determinasi $\left(\mathbf{R}^{2}\right)$}

Untuk mengetahui seberapa besar konstribusi yang diberikan oleh variabel independen terhadap variabel dependen maka dilakukan analisis determinasi. Dari Tabel 1.7 diperoleh angka $\mathrm{R}_{\text {Square }}$ atau koefisien determinan sebesar 0,389 yang berarti variant yang terjadi pada variabel Kinerja
(Y) karyawan adalah sebesar $38,9 \%$ ditentukan oleh variabel motivasi dan kompensasi, sedangkan sisanya atau sebesar $61,1 \%$ ditentukan oleh variabel lain yang tidak diteliti.

\section{Uji Hipotesis}

a. Uji Parsial (Uji t)

Dalam penelitian ini digunakan perhitungan uji $\mathrm{t}$ dengan taraf sigifikansi sebesar 0,05 (5\%). Dimana kriteria uji test ini adalah akan signifikan apabila nilai sig. <0,05. Dari hasil penelitian, didapatkan bahwa koefisien regresi, nilai $\mathrm{t}$ dan signifikansi secara parsial adalah sebagai berikut : 
Tabel 1.8

Uji Parsial (Uji t)

\begin{tabular}{|l|l|l|l|l|l|}
\hline \multicolumn{7}{|c|}{ Coefficients $^{\mathbf{a}}$} & \multicolumn{2}{|c|}{$\begin{array}{l}\text { Unstandardized } \\
\text { Coefficients }\end{array}$} & $\begin{array}{l}\text { Standardized } \\
\text { Coefficients }\end{array}$ & & \multirow{2}{*}{ Sig. } \\
\cline { 2 - 6 } Model & B & Std. Error & Beta & t & Sig. \\
\hline 1 (Constant) & 18.523 & 3.976 & & 4.659 & .000 \\
\hline Motivasi & .487 & .124 & .548 & 3.915 & .000 \\
\hline Kompensasi & .099 & .147 & .095 & .676 & .501 \\
\hline a. Dependent Variable: Kinerja Karyawan \\
\hline
\end{tabular}

Sumber : Output SPSS 22

1) Uji Hipotesis parsial untuk variabel Pelatihan

Hipotesis yang akan diuji pada bagian ini adalah :

$\mathrm{H}_{0}: \quad \beta 1=0$ artinya variabel motivasi secara parsial tidak berpengaruh secara signifikan terhadap variabel kinerja karyawan.

$\mathrm{H}_{1}: \quad \beta 1 \neq 0$ artinya variabel motivasi secara parsial berpengaruh secara signifikan terhadap variabel kinerja karyawan.

Dari Tabel 4.14, diperoleh nilai thitung sebesar 3,915 Sedangkan nilai $t_{\text {tabel }}$ untuk $n=80$ dan $\mathrm{dk}=\mathrm{n}-2=80-2=78$ pada taraf signifikansi $\alpha=0,05$ diperoleh $t_{\text {tabel }}$ $=1,991$. Karena nilai $t_{\text {hitung }}>t_{\text {tabel }}$ dan nilai taraf signifikansi $(\alpha)$ sebesar $0,000<0,05$, maka $\mathrm{H}_{0}$ ditolak dan $\mathrm{H}_{1}$ diterima. Sehingga dapat disimpulkan bahwa "Terdapat pengaruh yang signifikan antara motivasi terhadap Kinerja karyawan".

2) Uji Hipotesis parsial untuk variabel Kompensasi

Hipotesis yang akan diuji pada bagian ini adalah :

$\mathrm{H}_{0}: \quad B 1=0$ artinya variabel pengembangan karir secara parsial tidak berpengaruh secara signifikan terhadap variabel kinerja karyawan.

$\mathrm{H}_{1}: \quad B 1 \neq 0$ artinya variabel pengembangan karir secara parsial berpengaruh secara signifikan terhadap variabel kinerja karyawan.

Dari Tabel 4.14, diperoleh nilai $t_{\text {hitung sebesar 0,676 Sedangkan nilai }}$ $\mathrm{t}_{\text {tabel }}$ untuk $\mathrm{n}=80$ dan $\mathrm{dk}=\mathrm{n}-2=80-2$ $=78$ pada taraf signifikansi $\alpha=0,05$ diperoleh $t_{\text {tabel }}=1,991$. Karena nilai $t_{\text {hitung }}<t_{\text {tabel }}$ dan nilai taraf signifikansi $(\alpha)$ sebesar 0,501> 0,05, maka $\mathrm{H}_{0}$ diterima dan $\mathrm{H}_{1}$ ditolak. Sehingga dapat disimpulkan bahwa "Tidak terdapat pengaruh yang signifikan antara kompensasi terhadap Kinerja karyawan”.

\section{b. Uji Simultan (Uji F)}

Pengujian $F$ statistik adalah uji secara bersama-sama seluruh variabel independennya (motivasi dan kompensasi) terhadap variabel dependennya (kinerja karyawan). Perhitungan statistic $F$ dari ANOVA dilakukan dengan membandingkan nilai krisis yang diperoleh dari tabel distribusi $F$ pada tingkat signifikan tertentu.

Hipotesis yang akan diuji pada 
bagian ini adalah :

$\mathrm{H}_{0}: \quad \beta 1=\beta 2=0$, tidak ada pengaruh yang signifikan antara variabel motivasi dan kompensasi terhadap variabel kinerja karyawan.

$\mathrm{H}_{1}: \quad \beta 1 \neq \beta 2 \neq 0$ ada pengaruh yang signifikan antara variabel motivasi dan kompensasi terhadap variabel kinerja karyawan.
Sedangkan kriteria pengujiannya adalah :

Ho diterima apabila $F_{\text {hitung }}<\mathrm{F}_{\text {tabel }}$ atau

Signifikansi $F_{\text {hitung }}>\alpha$

Ho ditolak apabila $F_{\text {hitung }}>F_{\text {tabel }}$ atau

Signifikansi $F_{\text {hitung }}<\alpha$

Hasil pengujian simultan pengaruh variabel independen (motivasi dan kompensasi) terhadap variabel dependennya (kinerja karyawan) seperti ditunjukkan pada tabel 1.9 berikut:

Tabel 1.9

Hasil Uji Simultan (Uji F)

Motivasi dan Kompensasi terhadap Kinerja Karywan

\begin{tabular}{|c|c|c|c|c|c|}
\hline \multicolumn{7}{|c|}{ ANOVA $^{\text {a }}$} \\
\hline Model & $\begin{array}{c}\text { Sum of } \\
\text { Squares }\end{array}$ & df & $\begin{array}{c}\text { Mean } \\
\text { Square }\end{array}$ & F & Sig. \\
\hline Regression & 884.295 & 2 & 442.147 & 24.518 & $.000^{\mathrm{b}}$ \\
\hline Residual & 1388.593 & 77 & 18.034 & & \\
\hline Total & 2272.888 & 79 & & & \\
\hline \\
a. Dependent Variable: Kinerja Karyawan \\
b. Predictors: (Constant), Motivasi, Kompensasi \\
\hline
\end{tabular}

Sumber: Output SPSS 22

Dari tabel 1.9 dapat dilihat nilai $F_{\text {hitung }}$ adalah sebesar 24,518, sedangkan nilai $\mathrm{F}_{\text {tabel }}=\mathrm{F}_{(2 ; \mathrm{df})}=\mathrm{F}_{(2}$; $80-2)=3,11$ dengan nilai signifikansi $\mathrm{F}$ sebesar 0,000. Pengujian akan menolak Ho jika $p$-value $<\alpha$. Jika dibandingkan dengan taraf signifikan $\alpha=5 \%$ maka $p$-value $(0,000)$ bernilai lebih kecil dari $\alpha$ sehingga $\quad \mathrm{H}_{0}$ ditolak dan $\mathrm{H}_{1}$ diterima. Sehingga dapat disimpulkan terdapat pengaruh yang signifikan antara motivasi dan kompensasi terhadap kinerja karyawan pada PT Sumber Tenaga Lestari (Citylight Apartment) Tangerang Selatan).

\section{B. Pembahasan}

Berikut ini adalah pembahasan dari pengolahan data yang telah dijelaskan sebelumnya:

1. Pengaruh Motivasi terhadap Kinerja Karyawan

Berdasarkan hasil analisis perhitungan SPSS Versi 22, diperoleh nilai thitung untuk variabel Motivasi $\left(\mathrm{X}_{1}\right)$ adalah sebesar 3,915, sedangkan $\mathrm{t}_{\text {tabel }}$ untuk $\mathrm{n}=80 \mathrm{dk}=\mathrm{n}$ $2=80-2=78$ adalah sebesar 1,991 . Jadi karena nilai $\mathbf{t}_{\text {hitung }}>\mathbf{t}_{\text {tabel, }}$ yaitu $3,915>1,991$ dan nilai sig. 0,000 lebih kecil dari 0,05 (tingkat signifikansi 5\%) sehingga Ho ditolak dan Ha diterima maka dapat disimpulkan bahwa Motivasi $\left(\mathrm{X}_{1}\right)$ memang mempunyai pengaruh yang positif dan signifikan terhadap Kinerja karyawan (Y). 
2. Pengaruh Kompensasi terhadap Kinerja Karyawan

Berdasarkan hasil analisis perhitungan SPSS Versi 22, diperoleh nilai thitung untuk variabel Kompensasi $\left(\mathrm{X}_{2}\right)$ adalah sebesar 0,676 , sedangkan $t_{\text {tabel }}$ untuk $\mathrm{n}=80$ $\mathrm{dk}=\mathrm{n}-2=80-2=78$ adalah sebesar 1,991. Jadi karena nilai thitung $<$ ttabel, yaitu $0,676<1,991$ dan nilai sig. 0,501 lebih besar dari 0,05 (tingkat signifikansi 5\%) sehingga Ho diterima dan Ha ditolak maka dapat disimpulkan bahwa variabel Kompensasi $\left(\mathrm{X}_{2}\right)$ tidak mempunyai pengaruh yang signifikan terhadap Kinerja Karyawan.

3. Pengaruh Motivasi dan Kompensasi terhadap Kinerja Karyawan

Berdasarkan analisis hasil perhitungan analisa data pengaruh antara motivasi $\left(\mathrm{X}_{1}\right)$ dan kompensasi $\left(\mathrm{X}_{2}\right)$ terhadap kinerja (Y) ditunjukkan oleh regresi linier berganda $Y=18,523+0,487 X_{1}+$ $0,099 \mathrm{X}_{2}$ artinya meskipun tanpa adanya pengaruh variabel motivasi dan kompensasi, maka karyawan tetap memiliki tingkat kinerja sebesar 18,523. Untuk koefisien regresi sebesar 0,487 pada variabel motivasi merupakan koefisien arah regresi linear yang positif, artinya bahwa setiap kenaikan motivasi $\left(X_{1}\right)$ sebesar satu satuan, maka kinerja (Y) akan meningkat sebesar 0,487 dengan asumsi kompensasi $\left(\mathrm{X}_{2}\right)$ dianggap konstan. Koefisien regresi sebesar $=0,099$ pada variabel kompensasi, merupakan koefisien arah regresi linear yang positif, artinya bahwa setiap kenaikan kompensasi $\left(\mathrm{X}_{2}\right)$ sebesar satu satuan, maka kinerja (Y) akan meningkat sebesar 0,099 dengan asumsi motivasi $\left(\mathrm{X}_{1}\right)$ dianggap konstan. Hasil pengujian pengaruh simultan variabel bebas terhadap variabel terikatya diperoleh nilai $F_{\text {hitung }}=24,518>$ nilai $F_{\text {tabel }}=3,11$ sehingga Ho ditolak dan $\mathrm{Ha}$ diterima. Sehingga dapat disimpulkan terdapat pengaruh yang antara motivasi dan kompensasi terhadap kinerja karyawan. Dikarenakan nilai signifikansi variabel motivasi sig. $=0,000<0,05$ dan variabel kompensasi sig. 0,501>0,05, maka variabel motivasi berpengaruh secara signifikan sedangkan variabel kompensasi berpengaruh tidak signifikan.

Tingkat hubungan variabel bebas terhadap variabel terikat ditunjukkan nilai koefisien korelasi $\mathrm{R}$ sebesar 0,624, artinya motivasi dan kompensai memiliki hubungan yang cukup kuat terhadap Kinerja karyawan. Sedangkan konstribusinya ditunjukkan dengan nilai koefisien determinasi nilai $\mathrm{R}^{2}$ ( $\mathrm{R}$ Square) sebesar 0,389, yang berarti konstribusi motivasi dan kompensasi terhadap Kinerja karyawan, sebesar 38,9 \%, sedangkan sisanya sebesar $61,1 \%$ ditentukan oleh variabel lain yang tidak diteliti dalam penelitian ini.

\section{KESIMPULAN}

Dari hasil pengujian hipotesis dapat disimpulkan:

1. Secara parsial terdapat pengaruh positif dan signifikan Motivasi $\left(\mathrm{X}_{1}\right)$ terhadap Kinerja Karyawan (Y). hal ini dapat dibuktikan dengan nilai thitung untuk variabel Motivasi $\left(\mathrm{X}_{1}\right)$ sebesar 3,915, sedangkan $t_{\text {tabel }}$ $(1,991)$. Karena nilai $\mathbf{t}_{\text {hitung }}>\mathbf{t}_{\text {tabel, }}$ yaitu $3,915>1,991$ dan nilai sig. 
0,000 lebih kecil dari 0,05 (tingkat signifikansi 5\%) sehingga Ho ditolak dan Ha diterima ..

2. Secara parsial terdapat terdapat pengaruh positif dan signifikan Kompensasi $\left(\mathrm{X}_{2}\right)$ terhadap Kinerja Karyawan (Y). hal ini dapat dibuktikan dengan nilai thitung untuk variabel Motivasi $\left(\mathrm{X}_{1}\right)$ sebesar 0,676 sedangkan $t_{\text {tabel }}(1,991)$. Karena karena nilai $\mathbf{t}_{\text {hitung }}<\mathbf{t}_{\text {tabel, }}$ yaitu $0,676<1,991$ dan nilai sig. 0,501 lebih besar dari 0,05 (tingkat signifikansi 5\%) sehingga Ho diterima dan Ha ditolak.

3. Hasil analisa regresi berganda pengaruh antara motivasi $\left(\mathrm{X}_{1}\right)$ dan kompensasi $\left(\mathrm{X}_{2}\right)$ terhadap kinerja (Y) ditunjukkan oleh regresi linier berganda $Y=18,523+0,487 X_{1}+$ $\mathbf{0 , 0 9 9} \mathbf{X}_{2}$.Hasil pengujian pengaruh simultan variabel bebas terhadap variabel terikatya diperoleh nilai $F_{\text {hitung }}=24,518>$ nilai $F_{\text {tabel }}=3,11$ sehingga Ho ditolak dan $\mathrm{Ha}$ diterima. Sehingga dapat disimpulkan terdapat pengaruh yang antara motivasi dan kompensasi terhadap kinerja karyawan.

Tingkat hubungan variabel bebas terhadap variabel terikat ditunjukkan nilai koefisien korelasi $\mathrm{R}$ sebesar 0,624 , artinya motivasi dan kompensai memiliki hubungan yang cukup kuat terhadap Kinerja karyawan. Sedangkan konstribusinya ditunjukkan dengan nilai koefisien determinasi nilai $\mathrm{R}^{2}$ ( $\mathrm{R}$ Square) sebesar 0,389, yang berarti konstribusi motivasi dan kompensasi terhadap Kinerja karyawan, sebesar 38,9 \%, sedangkan sisanya sebesar $61,1 \%$ ditentukan oleh variabel lain yang tidak diteliti dalam penelitian ini.

\section{DAFTAR PUSTAKA}

Abdullah, Ma'ruf, "Evaluasi Kinerja Karyawan", Aswaja Pressindo, Ngangklik Sleman,

Yogyakarta, 2014

Bangun,Wilson, "Manajemen Sumber Daya Manusia", Erlangga, Jakarta, 2013

Fahmi, Irham, "Perilaku Organisasi Cetakan Pertama", Alfabeta, CV, Bandung, 2013

Handoko, T Hani, "Manajemen Personalia Cetakan Ke Sembilan", BPFE, Yogyakarta, 2007

Hasibuan, Malayu S.P, "Pengertian SDM", Alfabeta, Bandung, 2011

Iswanto, Yus \& Yusuf, Adhie, "Manajemen Sumber Daya Manusia", Universitas Terbuka, Jakarta, 2011

Mangkunegara, Anwar Prabu, "Evaluasi Kinerja Sumber Daya Manusia", PT. Remaja Rosda Karya, Bandung, 2014

M. Kadarisman," Pengertian Kompensasi", Edisi Revisi, PT. Bumi Aksara, Jakarta, 2012

PB, Trinton, "Pengertian Kompensasi", BPFE,

Yogyakarta, 2010

Sedarmayanti, "Manfaat MSDM", Edisi Revisi, PT. Bumi Aksara, Jakarta, 2007

Siagian, Sondang, "Pengertian Manajemen", Edisi Revisi, PT. 
Bumi Aksara, Jakarta,2012

Sihombing, Sarinah, "Manajemen Sumber Daya Manusia", INMEDIA, Jakarta, 2013

Simamora, Henry, "pengertian SDM", Edisi Revisi, PT. Bumi Aksara, Jakarta, 2014

Sugiyono, "Hipotesis", Edisi Revisi, PT. Bumi Aksara, Jakarta. 2011
Sutrisno, Edi, "Manajemen Sumber Daya Manusia", PT. Kencana Prenada Media Grup, Jakarta. 2009

Kencana Prenada Media Grup, Jakarta, 2016

Wibowo, "Organisasi Dan Manajemen Sumber Daya Manusia", PT. Rineka Cipta, Jakarta, 2012

Penulis:

Gatot Kusjono,Drs.,MM, Dosen Manajemen Universitas Pamulang

Putri Ratnasari, lulus Sarjana Ekonomi (2017) 